" . . - if I examine the nature of this proposition that 'the properties of matter might have been' other than they are. Does it express an experimentally-ascertained truth? If so, I invite Prof. Tait to describe the experiments !"

P. G. TAIT

\section{Animal Locomotion}

My former letter on this subject was merely to show that, mechanically, Dr. Pettigrew's view of the forward motion or inclination of a bird's wing during the down stroke was less absurd than had been supposed, and even seemed necessary to flight. I did not profess to have made accurate observation or experiment on the point. I accept, therefore, the observation of the Duke of Argyll as to the vertical motion of the heron's wing; but as he expressly refers to its great concavity, that would give a vertical down stroke the effect of a somewhat forward stroke of a flatter wing. The proper inference would therefore seem to be, that in birds with less concave wings the stroke is slightly directed forwards. As to the last two paragraphs of his Grace's letter, he will see, if he refers again to mine, that he has quoted words I never used. I impute to Dr. Pettigrew the "merit of showing "that the "slight upruard angle of the mean position of the wing plane is essential to secure horizontal forward motion as a general resultant," \&c., and this is exactly what the Duke denies.

Mr. James Ward's elaborate analysis of the down stroke of a bird's wing simply shows (if correct) that in the position he ascribes to it (moving downward and backward) it would send the bird horizontally forward. Of course it would. But then what becomes of the bird during the up stroke in an opposite direction? The bird is then falling, and by the downward reaction of all the solid surface of the anterior margin of the wing, and of all the feathers, however obliquely turned, it is driven farther downwards; and as this takes place between every two down strokes, and approximately during an equal space of time, how is a horizontal average motion to be produced unless the down stroke alone produces, not a horizontal, but a highly-inclined upward motion? Mr. Ward's whole argument appears to me to ignore the great downward reaction, added to gravitation, during every up stroke, which requires that the down stroke should not merely support the bird, but raise it up vertically just as much as during the up stroke it has fallen vertically. The matter, however, is not to be settled by discussing theoretically, but by observation and experiment. I simply maintain that the results of Dr. Pettigrew's observations and experiments are not, as supposed, inconsistent with mechanical principles; and nothing in your correspondent's letter induces me to alter that opinion.

\section{AlFRED R. WALLACE}

\section{The Newfoundland Cuttie-Fish (Mesaloteuthis harveyi S. Kent)}

M $\times$ right being questioned, through an anonymous paragraph in the Globe of the IIth inst., to institute a new generic title for the gigantic Cephalopod encountered off Newfoundland, and of which I communicated an account to the Zooloyical Society's meeting of March 3, I would briefly reply to my criticiser in these columns.

In the first place, it is a somewhat anomalous proceeding to raise objections on such a question before details of the grounds upon which it has been deemed advisable to establish such a title have appeared, as in the ordinary course of events they will, in the "Proceedings" of the Society. In these it will be found that ample reasons are given for the course that has been taken, as also due notice of both Prof. Steenstrup's and Prof. Verrill's researches in a similar direction. Had my assailant placed himself more thoroughly au courant with the details of the case, he would possibly have held back his emphatic assertion that Prof. Verri: 1 had "actually identified the species from Newfoundland with those described by Steenstrup as belonging to his genus Architeuthis." This identification in Prof. Verrill's own language is entirely problematical, and must unfortunately remain so, since a beak only, an organ of no value in generic discrimination, has been preserved of the typical species $A$. dux. Respecting the second form, $A$. monachus, we have still less knowledue, the title being provisionally instituted by Prof. Steenstrup for the recepiion of two gigantic Cephalopods cast on the shores of Jutland in the years 1639 and 1790 , and of which popular record alone remains.

In reference to the "imperfect evidence" asserted by my critic to be at my command, I may state that I received accounts of the examples, upon which I have proposed to base my new title of Megaloteuthis, direct from America as long ago as in the beginning of December last, supplemented by numerous fuller details since.

W. Saville-Kent

\section{Lord Lindsay's Expedition}

THE expedition of Lord Lindsay for observation of the Transit of Venus at Mauritius (why will people still call it the Mauritius?) will afford a good opportunity for re-measuring the base line of Abbé de la Caille, made in 1753 , and which, to the best of my belief, has never been since verified.

The small conical cairns which mark its extremities should still be found in situ. I saw one only of them in November 1864, when I had not time to search for the other. The base measured was $I, 828$ toises in length, and, I imagine, on the meridian. It was on a level plain at the south-west extremity of the island, close under the western slopes of the precipitous and noble "Morne du Brabant," which rises nearly I, 700 feet above the sea-level. By road the distance of this spot from Port Louis must be at least 30 miles, but it is much more easily reached direct by boat; or, as December is a bad time of year for boating outside the reefs, the best route would be from Black River by water inside the isle Bénitier. It is a glorious district, all that part of the island, and contains the finest scenery, including the Chamaral Falls.

Buncrana, near Londonderry, March 14

S. P. Oliver

\section{QUETELET}

$\mathrm{O}^{\mathrm{N}}$ February i7 last Jacques-Ädolphe-Lambert Quetelet died at Brussels, in the seventy-eighth year of his age, having been born on February 22, I796, at Ghent. At the early age of 18 he was appointed Professor of Mathematics in the College of his native town. In July, 1819 , the degree of Doctor of Science was conferred on him by the University of Ghent, then recently founded by King William. His dissertation on this occasion was so well received that he was shorly thereafter appointed to the Chair of Mathematics at the Royal Athenæum of Brussels; and in February following was elected a member of the Academy of Sciences and Belles-Lettres.

At this time he applied himself with ardour to the cultivation of literature and pure mathematics, thus laying a sure foundation for the world-wide fame he afterwards achieved as an exact investigator in many departments of physics, as an original thinker in applying methods of scientific treatment to the discussion of problems pre, viously considered as belonging exclusively to moralists and divines, and as a clear and eloquent expounder of the truths he had demonstrated. The many-sidedness and fertility of his mind may be seen from his scientific memoirs enumerated in the Royal Society's Catalogue of Scientific papers, amounting at the close of 1863 to 220 . $\mathrm{He}$ continued to write almost to the last, notwithstanding. the mental malady, consisting in loss of memory, with which he was afflicted many years before his death, and it is noteworthy that even to the last his handwriting retained much of the rare grace and elegance for which it had been so remarkable.

'The earliest of Quetelet's published memoirs, begun in I 820 , were on geometrical subjects. The non-appreciation of these by the public determined him to devote himself to physical science and astronomy. On these subjects he lectured publicly with great success.

In 1823 he was sent on a mission to Paris with the view. of preparing a report on the observatory of that city for the guidance of the Belgian Government in founding a similar observatory at Brussels. After some delay, the observatory was established, with Quetelet as director, and in 1833 began the long series of observations on astronomy, meteorology, and other physical inquiries, for which this observatory is so well known. The most important of his astronomical observations was the prepara- 